\title{
Àwọn Ìyà Awo, as senhoras do segredo na big apple: mulheres nas práticas de Candomblé na cidade de Nova lorque(EUA)
}

Àwọn lyà Awo, the ladies of secret in the big apple: women and Candomblé practices in New York City, USA

\section{Marcelo Máximo Niel}

Brasil. Faculdade Pitágoras de Medicina de Eunápolis. Doutor em Ciências pelo Departamento de Saúde Coletiva da Universidade Federal de São Paulo. Professor do Curso de Medicina da Faculdade Pitágoras de Eunápolis. ID ORCID: http://orcid.org/0000-0002-6796-0298.E-mail:marceloniel@me.com. Colaboração: redação, análise de dados, revisão.

\section{Pedro Paulo Gomes Pereira}

Brasil. Universidade Federal de São Paulo. Professor Associado da Universidade Federal de São Paulo. Professor do Programa de Pós-Graduação em Saúde Coletiva da Universidade Federal de São Paulo. Doutorado em Antropologia pela Universidade de Brasília (2001) e Pós-doutoramento na Universidade de Barcelona (2001-2002). ID ORCID: https://orcid.org/0000-0002-0298-2138. E-mail: pedropaulopereira@hotmail.com. Colaboração: redação, análise de dados, revisão.

\section{Resumo}

Durante a realização de uma etnografia sobre o Candomblé na cidade de Nova Iorque, destacou-se a presença de três mães de santo brasileiras que, levadas a dialogar e repensar as suas práticas no contexto norte-americano, reinventam as configurações religiosas tradicionais ou, melhor dizendo, inventam tradições, conforme o pensamento de Roy Wagner. Ao narrar as histórias dessas mulheres, pôde-se demonstrar de que forma elas reinventam o Candomblé, articulando segredos, permissões e traduções das suas práticas, fazendo, paradoxalmente, com que ele permaneça o mesmo, contribuindo para a propagação e para o estabelecimento da religião nesse novo lugar. Um dos pontos importantes encontrados nessa reinvenção foi a mudança no aspecto hierárquico, uma vez que as mães de santo adotam um sistema de interação mais horizontal com seus adeptos e clientes, em contraposição ao modelo mais verticalizado, como o prevalente nos terreiros brasileiros.

Palavras-chave: Candomblé, Nova Iorque, Mulheres.

Recebido em 29 de novembro de 2019 Avaliador A: 29 de janeiro de 2020 


\section{Abstract}

During the development of our ethnographic research about Candomblé practices in New York City, the presence of three Brazilian mães de santo ("mothers of saint") stood out. They have been led to rethink their practices in the context of life in the USA and to reshape standard religious configurationsin short, they have created new traditions, as per Roy Wagner's academic work. By telling the stories of these women, it was possible to reveal the mechanisms through which they have reinvented their religion: articulating secrets, permissions and transpositions related to their practices while also (and rather paradoxically) contributing to preserve the original essence of Candomblé. And by doing that, they have also helped spread and establish their religion in a foreign country. One of the most important aspects of the reinvention process concerns the so-called hierarchical changes; in New York, the relationship between the mães de santo and the practitioners is more horizontal than then one observed on the terreiros located in Brazil.

Keywords: Candomblé, New York, Women.

\section{INTRODUÇÃO}

O Candomblé é uma religião brasileira de matriz africana, formada a partir das influências culturais advindas da África pelos povos escravizados, caracterizada, segundo Goldman (2009), por um conjunto heteróclito, mas articulado, de práticas e concepções religiosas cujas bases foram trazidas pelos africanos escravizados e que incorpora elementos das cosmologias e práticas indígenas; assim como do catolicismo popular; e do espiritismo de origem europeia. A proposta da religião está sedimentada na realização terrena de bem-estar e bem-viver, valendo-se da resignação e da elaboração de estratégias mágicas que contribuem para a melhora da qualidade de vida, saúde física e mental e a prosperidade material. Nesse aspecto, o sacerdote, chamado de pai ou mãe de santo, ocupa um papel central porque, além dos adeptos, deverá atender à clientela que recorre aos seus serviços mágicos (GOMBERG, 2001; LIMA, 2010; PRANDI, 1996; SANTOS, 2009; ZIEGLER, 1977). 
Desde sua formação até os dias de hoje, observa-se uma importante expansão, a partir da Bahia - seu principal berço - para o restante do país e para outros países, como é próprio de uma religião universal. Segato (2005) descreveu um aumento desse fluxo para regiões e países onde a cultura ocidental é dominante, inscrevendo nestes novos contextos características de minorias outrora reprimidas e esquecidas. A intensificação desse trânsito parece ser um dos movimentos atuais do Candomblé, mas que, talvez devido às características de invisibilidade do imigrante brasileiro nos Estados Unidos, conforme descreve Margolis (1994), e também por se tratar de um fenômeno mais novo, se comparado ao movimento migratório dos povos hispânicos, ainda é pouco estudado. De acordo com a autora, os imigrantes brasileiros são pouco percebidos pelos habitantes de Nova Iorque e facilmente confundidos com os imigrantes hispânicos, além de desenvolverem uma relação de "estadia provisória", com menos representatividade no cotidiano da cidade, mesmo com o paradoxal interesse por "coisas do Brasil", como comida e capoeira (MARGOLIS, 1994, p. 17). Embora esse trânsito em direção a outras partes do globo já ocorra há algumas décadas, somente mais recentemente os pesquisadores têm se dedicado ao tema. Se existe um denominador comum entre suas conclusões, é justamente a constante reinvenção de suas práticas em cada novo destino (BAHIA, 2012; CAPONE, 2010; GOLDMAN, 2009; GOMBERG, 2001; ORO, 1998; PORDEUS, 2000; PRANDI, 2005; SILVA, 1995).

Foi esse fluxo e essas viagens que atraíram a curiosidade e levaram a iniciar esta pesquisa, realizada entre 2013 e 2017, a partir de uma primeira informação de que havia uma mãe de santo da Bahia que possuía clientes em Nova Iorque e que permanecia metade do ano atendendo pessoas na cidade. À medida que se dava a aproximação com as práticas do Candomblé em Nova Iorque, que conhecia sua relação com aquele espaço urbano e suas reinvenções, as primeiras conexões e interlocutores conduziram ao encontro com três mães de santo brasileiras, que contaram suas histórias e falaram sobre como o Candomblé era reinventado em Nova Iorque.

A partir da constatação da presença dessas sacerdotisas e de suas práticas singulares, delinearam-se alguns questionamentos, que serão respondidos ao 
longo desse artigo. Inicialmente, descreve-se o percurso dessas mães de santo ao encontro da religião e da cidade de Nova Iorque, quais as particularidades de suas práticas nesse contexto e quais foram as reinvenções por elas realizadas. Num segundo momento, explora-se o modo como elas estabelecem a função sacerdotal, que evidencia diferenças do modelo hierárquico prevalente nos Candomblés brasileiros, adotando, em Nova Iorque, um novo sistema, mais horizontalizado, de relações. Num terceiro e último momento, realiza-se um questionamento: quais as consequências das constantes reinvenções operadas pelas três mães de santo?

\section{MÉTODO}

O trabalho de campo realizou-se entre janeiro de 2013 e fevereiro de 2017, caracterizado por diversos encontros com três mães de santo que praticavam rituais de Candomblé na cidade de Nova Iorque. Esses encontros aconteceram em Nova Iorque (EUA), São Paulo (SP) e Salvador (BA). Durante a pesquisa etnográfica, por meio de observação participante e acompanhamento da vida cotidiana dessas mães de santo, estabeleceu-se um vínculo mais intenso com essas sacerdotisas e, pouco a pouco, foi possível apreender delas como se dava o funcionamento da religião nessa cidade. Ao falar de um "vínculo mais intenso" com as mães-de-santo, deve-se deixar claro que, pelas próprias características da religião, como a transmissão oral do conhecimento e a importância dada ao segredo das informações, além da situação peculiar de que tais práticas religiosas seguem de forma clandestina, esse processo de conquistar a confiança das entrevistadas deu-se de forma gradual, ao longo de muitas conversas.

É importante salientar que, sendo iniciado ${ }^{1}$ no Candomblé há alguns anos, essa ligação com a religião também contribuiu para que desejasse estudá-la mais a fundo. Nos estágios iniciais da pesquisa, o fato de ser iniciado na religião

\footnotetext{
A iniciação do Candomblé, também chamada de "feitura", é um processo caracterizado por um período de reclusão que dura cerca de trinta dias, com a realização de diversos rituais, cujo principal objetivo é uma forma de renascimento para a vida espiritual, marcada pela devoção ao seu Orixá principal ou "Orixá de cabeça".
} 
facilitou a entrada no campo, por possuir algum domínio sobre a linguagem própria do Candomblé. Além disso, ser iniciado conferiu um acesso, ao menos parcial, às práticas por elas realizadas. Esse acesso foi parcial porque cada sacerdotisa possui seu próprio sistema de segredo, seu próprio awo (palavra iorubá que significa segredo, mistério). E o segredo, no Candomblé, é a chave para a manutenção do poder. Grande parte dos sacerdotes concorda que, quando se revela um segredo, o poder mágico ou a força, chamada de axé, se esvai. Esse é, sem dúvida, o primeiro grande obstáculo a ser transposto: essa "delicada costura" do que é contado, mas, não pode ser revelado, porque trai um princípio ético com aquele universo pesquisado, e trai a relação de confiança estabelecida, delicadamente, com tempo e paciência, com os interlocutores.

Além do awo, mergulhar nesse campo esbarra em outro tipo de segredo: olugar "não oficial", até mesmo "clandestino", dessas práticas em terra estrangeira. Um pesquisador, até que se prove o contrário, é um "intruso" em potencial, seja do governo, de religiões concorrentes, ou mero curioso. Awo e clandestinidade se articulam e engendram uma muralha de dificuldades para ter acesso às informações desejadas para a pesquisa. É claro que esse processo de estabelecer vínculo está presente sempre, seja qual for o objeto da pesquisa; o que se destaca aqui é a especificidade desse encontro.

Além dos encontros com as sacerdotisas, foram consultados alguns pesquisadores de diversas áreas, como Stefania Capone (2010) e Loránd Mattory, especialistas em religiões de matriz africana; Maxime Margolis (1994), que realizou uma importante pesquisa sobre imigrantes brasileiros em Nova Iorque; e, Fabiana Fonseca, uma farmacêutica especializada em etnobotânica que realizou uma pesquisa sobre o uso das plantas entre os sacerdotes em Nova Iorque; além de duas analistas junguianas (Andrea Hunt; Beverley Zabriskie) moradoras da cidade, que possuíam relação de clientela com uma das sacerdotisas e que contribuíram com alguns fundamentos relativos à psicologia analítica como uma forma de expansão simbólica da compreensão do fenômeno. Manteve-se, também, interlocução com alguns sacerdotes, como a mãe de santo pessoal e outros adeptos da religião, que auxiliaram na compreensão das práticas, fossem elas convergentes ou divergentes do que é praticado no Brasil. 
Alguns encontros foram registrados em áudio, outros em vídeo. Em certos casos, onde pareceu que a gravação das entrevistas representaria, de algum modo, uma ameaça ao vínculo de confiança estabelecido, optou-se por não efetuar nenhum tipo de registro e as informações foram anotadas no caderno de campo. Aos poucos, trocando mensagens, telefonemas e após algumas tentativas frustradas de encontros, a permissão para adentrar esse universo foi dada e a "magia" começou a acontecer. E essa magia só pôde acontecer quando, conforme descreveu Favret-Saada (1990), o pesquisador pode ser "afetado" por esse contato, adentrando à realidade dessas pessoas como um parceiro e, em vez de um mero observador, foi aceito e reconhecido como um igual, um irmão de santo, como se chamam uns aos outros na religião, recebendo a permissão, ou agô, em iorubá, para estar naquele lugar.

Do mesmo modo que aprendido durante esses anos como adepto do Candomblé, nada se faz sem pedir licença na religião. Licença para entrar, licença para sair, licença para tocar um objeto sagrado, licença para se aproximar de um sacerdote mais velho e pedir a bênção ou um conselho. Por vezes, essa licença foi dada na consulta ao jogo de búzios; em outras, pela indicação de alguém conhecido da confiança delas e, por último, por meio do consentimento de uma entidade espiritual. Ou seja, esse consentimento vem sempre através de um elemento externo, um outro que representa a permissão do Orixá.

Outro aspecto de extrema importância no Candomblé e que influenciou o andamento da pesquisaé a questão do tempo, ou İgbà, em iorubá (PRANDI, 2005). O tempo no Candomblé é diferente do tempo cronológico do mundo ocidental. É bastante comum ouvir dos sacerdotes e iniciados que "tudo tem seu tempo", "tudo tem a hora certa" e essa premissa influencia os momentos dos encontros e a revelação dos segredos, mesmo numa cidade apressada e marcada pelo relógio, como Nova Iorque. Assim, quando se entende a agência do tempo no Candomblé, onde se faz necessário saber esperar para que os segredos se revelem para o pesquisador, após dadas as devidas permissões, é esse o momento em que ocorre a "magia" do encontro e o campo se desenrola, em um ambiente diferente do usual, com seus segredos e sua linguagem inerentes à religião, mas, com peculiaridades derivadas da reinvenção de suas práticas 
em terra estrangeira. No momento em que se passa a fazer parte, afetados pela experiência, ou, "enfeitiçados" pelo culto, como ressaltou Silva (2000), tem-se a permissão, o agô para participar da experiência, mas, se comprometendo a preservar o segredo, o awo, revelando somente o que é permitido.

\section{CANDOMBLÉ EM TRÂNSITO}

Quando o Candomblé viaja para fora do Brasil, leva consigo certa bagagem, composta de saberes, premissas e símbolos. Também é verdade que ele terá que deixar uma parte da bagagem na origem. E, ao aportar em terra estranha com essa bagagem "exótica”, ele irá se deparar com a "alfândega” cultural e concreta daquele novo lugar. E terá que travar negociações com o espaço, com a lei e todos os códigos preestabelecidos, para somente então fixar-se e dar continuidade às suas operações, mas, ele já estará modificado.

O primeiro fato que chama atenção nas práticas das três sacerdotisas diz respeito ao território, ou, melhor dizendo, à ausência ou adaptação de um espaço específico, o espaço “terreiro”. De acordo com Muniz Sodré (1988), o terreiro representa uma forma de reterritorializar o patrimônio simbólico, afirmando-se no Brasil como território político-mítico-religioso. Neste espaço físico, a terra, o Aiyé, representando o mundo visível, guarda em si os segredos do mundo invisível, o Orun. Desse modo, conforme afirma Costa Lima (2003), o Candomblé seria um sinônimo do próprio espaço de culto. Nesse aspecto, as três sacerdotisas adotam atitudes divergentes quanto à necessidade de um espaço consagrado: segundo Pimpa, muitas das práticas do Candomblé não poderiam ser realizadas justamente pela ausência deste local específico; Regina não só considera perfeitamente possível, como executou, por mais de uma vez, rituais de iniciação em diversos adeptos da religião; Bárbara também acredita que rituais que considera mais complexos, como a iniciação, não poderiam ser realizados fora desse espaço-terreiro específico. Por outro lado, ela é a única das três sacerdotisas que possui um espaço consagrado num prédio residencial num subúrbio de Nova Iorque. É possível pensar que, por se tratar de 
um fenômeno recente, essas primeiras pessoas, precursoras das práticas de Candomblé nesse novo local, vão aos poucos levando seus conhecimentos e apetrechos para, paulatinamente, instalarem-se, elas próprias ou seus seguidores, de modo mais "definitivo", num território fixo, passando a constituir esse território-terreiro.

Na experiência do campo, foi possível observar que não apenas as práticas rituais são modificadas, mas também as relações com os clientes e adeptos. Enquanto no Brasil há uma maciça presença de sacerdotisas comandando terreiros e, mais que isso, implicadas num sistema matrilinear de sucessão, o mesmo não acontece em Nova Iorque. Nas práticas das três mães de santo na cidade, o sistema hierárquico verticalizado não está necessariamente rompido, mas atenuado, e as relações das mães de santo com seus clientes e adeptos se estabelecem mais como um sistema de parceria e colaboração mútua. A estrutura sucessória praticamente inexiste, uma vez que o trabalho das três mães de santo se dá de forma mais individual e em alguns casos, sobretudo em rituais mais complexos nos quais elas necessitem de ajuda de outras pessoas, acabam por contar com a colaboração de outros adeptos, iniciados e sacerdotes.

Embora atenuada, a noção de poder está presente no imaginário das três mães de santo e reafirmada na responsabilidade assumida em suas práticas, desde a sua iniciação até receberem a outorga do posto de mãe de santo, os chamados "direitos", das mãos dos sacerdotes que as iniciaram. Ao realizarem a consulta ao jogo de búzios para os clientes e adeptos e ao prescreverem banhos, defumações, beberagens, ebós - rituais de limpeza ou de aporte da energia espiritual em que se passam diversos alimentos e objetos no corpo da pessoa (COSSARD, 2006) - e boris - rituais que precedem a iniciação e se caracterizam pela oferta de diversos alimentos a Oxalá e Iemanjá como forma de preparar a cabeça para receber o Orixá durante a iniciação - além de tantas outras práticas possíveis, estão exercendo sua autoridade enquanto sacerdotisas, funcionando, muitas vezes, como um princípio organizador na vida daquelas pessoas que recorrem a elas. Como afirmou Dumont (1997), uma hierarquia das ideias, das coisas e das pessoas é indispensável à vida social e, em muitos casos, a hierarquia se identificará de alguma maneira com o poder. Ou seja, 
embora se trate de um contexto bastante diferente, num outro território e com outros significantes, ainda assim, trata-se de um lugar onde o exercício do poder feminino é observado, conforme ressaltou Marlise Silva (2010).

Durante o trabalho de campo em Nova Iorque, foi possível acompanhar as práticas dessas três grandes sacerdotisas. Elas são apresentadas numa sequência que obedece a uma provável linha histórica de suas chegadas, porque houve, nas conversas e entrevistas, um jogo de memórias e reconstruções do momento de início da jornada, como se as narrativas se recusassem a marcar o tempo exato dessa ocorrência.

\section{MÃES DE SANTO NA BIG APPLE}

\section{Pimpa, a sacerdotisa de Oxalá}

Oxalá é um orixá masculino, velho e sábio, ao qual a criação do mundo é atribuída em diversos mitos iorubás. Ele é considerado pai de todos, por representar o início, a origem (VERGER, 2000). Pimpa, filha de Oxalá, protagoniza, com sua chegada em Nova Iorque, a missão de seu orixá regente. Foi a pesquisadora Stefania Capone, em nosso primeiro encontro, em 2015, durante sua estada no Rio de Janeiro, que mencionou a importância de encontrar com Pimpa, por ter sido, ao menos oficialmente, a primeira brasileira a praticar Candomblé em Nova Iorque. O encontro com Pimpa ocorreu em 2015, em sua casa, em São Paulo. Ela estava com setenta anos, padecia de um câncer terminal e faleceu três meses após o encontro.

Antes de sua entrada no culto, trabalhava como psicóloga e possuía uma editora em São Paulo. Em 1977, editou uma compilação de textos sobre Candomblé traduzidos para o português, e contou que procurou um pai de santo para descobrir, mesmo sendo ateia, qual era seu "Orixá de cabeça”, para colocar uma roupa que combinasse com o Orixá no evento de lançamento do livro. Nesse jogo, teve a revelação de que deveria ser iniciada na religião e que tinha "cargo", ou seja, que possuía a missão de ser mãe de santo. A princípio, não acreditou em tais revelações, mas, ouviu a mesma coisa de outros 
sacerdotes e, numa cerimônia, foi tomada em possessão pelo Orixá, fenômeno conhecido como "bolar no santo", que se configura geralmente como um pedido do Orixá pela iniciação daquela pessoa. Iniciação, feitura ou "fazer o santo", é o processo pelo qual o adepto passa recluso cerca de vinte a trinta dias, para ser iniciado nos segredos da religião e que caracteriza uma espécie de nascimento para a vida espiritual dedicada ao Orixá. Passado algum tempo, ela foi iniciada, tornou-se mãe de santo e acabou iniciando vários filhos de santo.

Pimpa relatou que uma de suas filhas havia nascido em Nova Iorque e que, passados alguns anos, seus outros filhos mais novos resolveram ir morar lá e ela acabou indo com eles para fornecer-lhes o visto de permanência. Ela descreveu que sua intenção era "fugir" do Candomblé, porque acreditava que cuidar de um terreiro e de filhos de santo era algo muito trabalhoso. Mesmo assim, sempre recorria aos búzios (o sistema oracular da religião) para ter permissões e orientações. Ela disse que pretendia ficar seis meses em Nova Iorque, mas, acabou ficando dez anos, porque seu Orixá não permitia que ela fosse embora. Durante esse período, acabou praticando o Candomblé lá, e só voltou quando Oxalá, seu Orixá de cabeça, deu-lhe permissão, através do jogo de búzios.

Durante a sua permanência em Nova Iorque, Pimpa encontrou sacerdotes da Santería, nome que se dá à religião de matriz africana formada na América Central, bastante encontrada nos Estados Unidos (CABRERA, 2004). Esses sacerdotes eram, sobretudo, cubanos, e Pimpa permaneceu associada a eles durante muitos anos. Segundo ela, havia interesse deles em conhecer as práticas realizadas no Candomblé, porque eram mais completas e complexas do que as práticas da Santería. Ela relatou que realizou o primeiro ritual de bori nos Estados Unidos, no início dos anos de 1980, e por vários anos ensinou e supervisionou as práticas desses sacerdotes. Além do contato com eles, ela jogava búzios, fazia boris e ebós. Sua clientela era composta de brasileiros, hispânicos e negros americanos. Pimpa contou que também levou algumas pessoas para serem iniciadas no Candomblé no Brasil e que iniciou pessoalmente três cubanos, também no Brasil, sobretudo, pelas dificuldades em realizar o processo de iniciação nos Estados Unidos, devido à escassez de materiais, 
limitações de espaço físico, dificuldades na realização de rituais públicos e de sacrifícios.

Ela apontou que a principal dificuldade que encontrou no Candomblé no Brasil era o sistema hierárquico vigente. Ela relatou:

Eu acho que a causa principal é porque você convive diariamente, por muito tempo, com as pessoas e aquilo cansa e num sistema que eu acredito ser imperialista, onde o pai de santo pode falar a maior bobagem do mundo e todo mundo diz amém, axé. E não tem cabimento... Eu já ouvi coisas e aí, se alguém retrucar... O mundo não é mais assim. Eu nunca passei bronca em ninguém... quer dizer, passo bronca, mas chamo, no canto, vamos lá, conversar, explicar. Mas gritar, como eu vejo, jamais. O que eu não faço com filho meu eu não faço com filho de santo... acho que é claro isso. Todos são humanos, seres humanos. E acho que há um processo de transferência muito psicoterapêutico entre pai e filho de santo... então fica dependente de tudo... eu sou uma pessoa extremamente independente, criei meus filhos de forma extremamente independente, por que eu vou querer um monte de gente dependente? Não faz sentido...

Pimpa retornou ao Brasil após esses dez anos e continuou as suas atividades como mãe de santo até que resolveu fechar o seu terreiro e frequentar, no final de sua vida, os terreiros de sacerdotes amigos.

\section{Regina, a sacerdotisa de lemanjá}

Iemanjá é uma Orixá feminina, identificada simbolicamente como a Grande Mãe. No Candomblé, é considerada a mãe de todas as cabeças, sendo que suas principais funções são a maternagem e o equilíbrio da mente (VERGER, 2000). Regina foi a primeira sacerdotisa de quem se teve conhecimento na pesquisa. É uma mulher branca, de baixa estatura, com aproximadamente 79 anos de idade e cinquenta de iniciação. Casada, com três filhos. Em sua casa em Salvador, no bairro de Amaralina, ela atende seus clientes. Tem um pequeno terreiro instalado nos cômodos da sua própria casa, onde cuida dos 
seus santos e dos santos de sua falecida mãe, além de suas obrigações junto ao seu terreiro de origem, o Gantois.

No primeiro encontro com ela, foi realizada uma consulta aos búzios, e entre uma previsão e outra, ela contava sobre sua experiência em Nova Iorque. Segundo ela, começou a ir à Nova Iorque nos anos 1980, não lembrava uma data precisa, mas, assegurou que fazia mais de trinta anos. Ela não chegou a morar continuamente nos Estados Unidos, mas, permanecia na cidade cerca de seis meses por ano, entre março e setembro. Relatou que gostava tanto de viver lá que, não fossem as obrigações com o Gantois, moraria lá para sempre.

Suas atividades relativas ao Candomblé em Nova Iorque eram as consultas com o jogo de búzios e, através dele, a prescrição de banhos e ebós. Fez referência também à realização de uma Trezena de Santo Antônio, uma cerimônia católica sincrética comumente realizada pelos adeptos do Candomblé na Bahia. Relatou, também, que havia feito um "barco", nome comumente usado para designar o processo de iniciação, composto por 13 iaôs, ou iniciados, há alguns anos. Sobre esse barco, contou que ela e outros sacerdotes alugaram uma casa numa praia próxima da cidade e realizaram todos os preparativos para o processo de feitura. No último encontro com ela, no início de 2017, ela relatou que iria para a Califórnia para iniciar mais 13 pessoas.

Regina mencionou o nome de outras duas mães de santo, duas irmãs baianas que moravam em Nova Iorque e que haviam sido iniciadas na Bahia. Contou que eram suas grandes parceiras nas atividades que desempenhava em Nova Iorque. Essas duas mulheres foram contatadas durante a realização do campo, mas não houve sucesso em realizar algum tipo de encontro, nem mesmo por teleconferência ou por mensagens.

A sua clientela era formada, principalmente, por brasileiros de todos os níveis sociais, mas também por americanos afrodescendentes que sentiam necessidade de contato com suas raízes e até mesmo por adeptos da Santería. Segundo ela, essas pessoas que vivem lá, até mesmo os americanos e os hispânicos, sentem necessidade de vivências espirituais ligadas à África e, embora os cubanos tenham suas práticas, ela disse acreditar 
que o conhecimento que há no Brasil é mais completo e que eles precisam aprender mais.

Portanto, Regina, como filha de Iemanjá, exerce seu trabalho em consonância com a influência de sua mãe: ela cuida de cabeças, faz santos (iniciações) e exerce, com sua paciência e doçura, uma forma de maternagem.

\section{Bárbara, a sacerdotisa de lansã}

Iansã é a Orixá feminina guerreira, dos ventos, das tempestades e das faíscas. Por suas características, ela rege o movimento e os caminhos (VERGER, 2000). E é desse modo que Bárbara, a terceira mãe de santo deste estudo, executa suas práticas em Nova Iorque. Bárbara foi o maior desafio do campo. Um amigo, que morou alguns anos em Nova Iorque, deu a informação sobre sua existência ao saber do tema da pesquisa. Mesmo com a indicação dele, houve uma grande dificuldade inicial em conseguir marcar um encontro, mas, pouco a pouco, foi-se estabelecendo uma relação de confiança. Bárbara é natural de Niterói, tem 55 anos e mora há trinta anos em Nova Iorque. É casada e tem um filho. Iniciou-se no Candomblé há 25 anos. Em todos os encontros, ela esteve acompanhada de seu esposo, que é seu braço direito e uma espécie de guardião.

Bárbara contou que, quando morava no Rio de Janeiro, frequentava a Umbanda - uma religião de matriz africana que funde elementos da cultura africana, indígena e elementos do espiritismo -, caracterizada sobretudo pela incorporação de guias espirituais que dão consultas aos fiéis (SILVA, 1994). Ela contou que chegou a ouvir de cartomantes e guias espirituais que tinha uma "missão" espiritual a cumprir, mas, relatou que fugia disso no início porque se achava muito jovem para esse tipo de responsabilidade. Migrou para Nova Iorque na década de 1980 e desenvolveu sua mediunidade com uma mãe de santo que era iniciada no Candomblé, mas, que fazia rituais de Umbanda. Alguns anos mais tarde, teve contato com outra mãe de santo do Candomblé que foi ao restaurante onde trabalhava para fazer um ebó. Foi então que ela começou a entender e a se interessar pela religião. Em 1992 iniciou-se no 
Candomblé no Rio de Janeiro. Seu marido e seu filho permaneceram em casa de parentes na cidade durante todo o processo de iniciação.

Desde a sua feitura, Bárbara ouvia dos sacerdotes que ela tinha missão de ser mãe de santo. Disse que relutava em assumir essa posição, mas foi estudando e se dedicando e, aos poucos, aceitou essa responsabilidade. Seu percurso no Candomblé foi caracterizado por várias rupturas, chegando a mudar de terreiro três vezes porque, segundo ela, havia várias coisas com as quais não concordava nas casas por onde passou, sobretudo, o abuso de autoridade, o controle excessivo de ensinamentos e conhecimentos como forma do sacerdote manter o poder, criando, assim, uma atmosfera de medo sobre os filhos de santo; além da exploração, fosse ela financeira ou na realização de atividades, bem como as fofocas no ambiente de terreiro.

Ela disse que sua missão é praticar o Candomblé em Nova Iorque, mas, que é impossível praticar a religião como se faz no Brasil. Os motivos apontados por ela para essa impossibilidade foram: o espaço físico, as dificuldades legais relacionadas às práticas, a necessidade de adaptação dos rituais pela questão da limitação do uso do espaço público, a escassez de materiais e os cuidados com o tratamento da clientela, pelo risco de queixas e processos. Segundo ela, muita coisa precisa ser substituída ou adaptada. O próprio ritual, as festas e toques do Candomblé, dificilmente são realizados. Ela disse acreditar que o Orixá tem sabedoria para compreender as traduções que são feitas e aceitar as mudanças. Do mesmo jeito que o culto africano aos Orixás chegou ao Brasil modificado, ele também se modificou, se transformou, ao chegar em Nova Iorque e em outros lugares do mundo, como uma maneira de sobreviver.

Suas atividades são o jogo de búzios e a realização de ebós, banhos e outras prescrições, mas, não apenas isso. Bárbara mantém consigo, até hoje, a tradição dos guias de Umbanda, realizando festas e louvações a essas entidades, sobretudo, no período do verão, antes mesmo da ligação com o Candomblé. Ela falou que acreditava que nunca poderá realizar um Candomblé como se vê no Brasil e que sua atividade se constitui mais como uma orientadora de caminhos do que uma guardiã de cabeças. Sua clientela é composta principalmente de brasileiros, mas, também há estrangeiros trazidos por brasileiros. 
Ela relatou que tem uma clientela fiel, mas que também há grupos de pessoas que vão e voltam e diferentes grupos passaram pela sua casa.

A partir do encontro com essas mulheres, destacam-se alguns pontos-chave para a compreensão desse fenômeno: todas elas receberam a informação, através do jogo de búzios, que possuíam uma "missão" na religião e "cargo" de mães de santo; encararam seu percurso à cidade de Nova Iorque como parte dessa missão; relataram a necessidade de reinvenção de suas práticas em relação às formas de execução no Brasil; e adotaram um sistema de interação diferente com adeptos e clientes, rompendo ou atenuando o sistema hierárquico vigente no Brasil. Embora suas práticas apresentem similaridades, cada uma delas se relacionou com contextos diferentes e criou o seu próprio.

\section{SENHORAS DA MEDIAÇÃO}

A presença e a importância das mulheres na organização e preservação da religião são ressaltadas por diversos autores, desde os primeiros estudos antropológicos versando sobre o tema. Entre eles, destaca-se o livro Cidade das Mulheres, publicado em 1947, pela etnóloga americana Ruth Landes, no qual descreve o seu encantamento com o poder das mulheres sacerdotisas em alguns terreiros de Salvador (SILVA, 1994).

Seu trabalho foi bastante criticado pelo fato de Landes ter se apoiado na visão dos primeiros pesquisadores que a antecederam, como Nina Rodrigues, Édison Carneiro e Arthur Ramos, que elegeram, arbitrariamente, terreiros como o Gantois, a Casa Branca e o Opô Afonjá, todos dirigidos por mulheres e pertencentes à "nação" ketu, vertente do Candomblé que reúne elementos religiosos da cultura iorubá (SILVA, 1994), como os terreiros "tradicionais" de Salvador, em detrimento de tantas outras casas de Candomblé, equiparáveis em igualdade e tradição, pertencentes a outras nações e, não raras vezes, dirigidas por homens. Essa eleição arbitrária predominou por muitos anos nas pesquisas sobre o tema. 
Apesar das críticas pertinentes ao trabalho de Landes, é importante refletir sobre o fato de que ele trouxe luz à questão da presença de mulheres negras enquanto dirigentes de importantes lugares religiosos, ressaltando esses lugares de poder numa época em que seus direitos eram ainda mais escassos. Dentro de uma sociedade predominantemente patriarcal, a maioria das posições sacerdotais, das mais diversas religiões, é ainda masculina e uma mulher afrodescendente ocupar tal posição configura, de fato, um lugar de empoderamento feminino e racial, mesmo sem apoiar-se nesse equivocado pressuposto de tradição e pureza.

Sabe-se que a organização do culto e das práticas rituais do Candomblé obedece a divisões de tarefas e responsabilidades orientadas pelos gêneros, atribuindo-se funções masculinas e femininas correspondentes a essas funções na sociedade (AMARAL, 1992).

Assim sendo, sobretudo nos terreiros mais antigos e, em muitos deles até os dias de hoje, aos homens heterossexuais que eram condecorados como ogãs, um cargo sacerdotal masculino, geralmente eram dadas as tarefas de organização física do terreiro, atividades externas, como apanhar folhas no mato e trazer os animais utilizados, o manejo da faca nos rituais de sacrifício, o manejo dos instrumentos de percussão, a proteção, a segurança e a divulgação social dos terreiros. Ao mesmo tempo, eram proibidos de dançar na roda e entrar em transe (AMARAL, 1992).

Às mulheres, eram dadas as funções de arrumação e limpeza, cozinhar para alimentar a família de santo, cozinhar as comidas rituais, cuidar de panos e roupas utilizados, entre outras. Em muitos terreiros, sobretudo no passado, homens homossexuais assumidos e transexuais não eram aceitos nas atividades do culto. Com o passar do tempo, passaram a ser aceitos para dançar na roda e realizar outras atividades atribuídas às mulheres, exceto a cozinha, fato que perdura até os dias de hoje. Na hora da refeição, sentam-se à mesa apenas os iniciados mais velhos, com títulos de pai ou mãe de santo e ogãs, e os homens são sempre servidos em primeiro (AMARAL, 1992).

A posição máxima no terreiro pode ser ocupada por mulheres, mas, as estruturas de divisão de funções e tarefas por gênero permanecem. 
Embora atualmente seja frequente encontrar variações na organização das casas com relação ao gênero, são comumente consideradas pelos dirigentes "tradicionais" como aberrações e desvios (AMARAL, 1992, p. 92). Em seu estudo sobre o papel das mulheres no Candomblé de Cachoeira (BA), Iriart (1998) ressaltou que o culto oferece às mulheres um campo simbólico e um espaço de prática que lhes permite empreender uma crítica sobre a ordem sociocultural e comparou essa atividade ao que Scott (1990, p. 53) chamou de "formas cotidianas de resistência" (every day forms of resistance) e que Jean e John Comaroff $(1991,1997)$ descreveram como uma resistência coletiva não consciente.

As sacerdotisas que dedicaram seu tempo compartilhando suas experiências para a realização dessa pesquisa não são apenas Àwọn İyá Awo, ou as Senhoras do Segredo. Em seus percursos e práticas, elas detêm outras importantes funções, como a mediação (ilàjà) e a tradução (itúmộ) que, articuladas com o awo, estabelecem um sistema de funcionamento da religião e a manutenção do axé nesse novo lugar.

O axé não é uma força estática; é um processo dinâmico de movimentação de energia, que aumenta conforme ritos e atitudes, que, por sua vez, configuram alimentos que são ofertados aos Orixás. Tudo no Candomblé tem vida e energia e, tendo vida, alimenta-se. Come os Orixás, come os objetos sagrados, come a cabeça no ato da iniciação e come também o chão do terreiro, conhecido como cumeeira, local onde, primeiramente, plantou-se o axé do terreiro e são realizados os ritos de iniciação posteriores. Se existe o ato concreto de plantar o axé, pode-se dizer que existe um cultivo, uma semeadura, ou seja, um preparo dessa nova terra que sediará um novo terreiro. Simbolicamente, suas reinvenções representam esse preparo (PRANDI, 2005).

Das três sacerdotisas, Regina foi a única que explicitou a realização das práticas religiosas como única motivação da sua ida para Nova Iorque. Por outro lado, Pimpa e Bárbara migraram por razões pessoais alheias à religião - embora considerem que foram "levadas" para esse novo rumo pelos Orixás - e essa construção de sentido, da motivação religiosa e de uma missão nesse novo lugar, foi acontecendo passo a passo. As três sacerdotisas descreveram que sentiam, desde sua chegada, que havia uma necessidade de contato das pessoas de Nova Iorque com os ensinamentos 
do Candomblé, como uma forma mais "pura" de contato com a ancestralidade, com a África-Mãe. Nesses anos de permanência, tiveram contato com hispânicos a americanos afrodescendentes que traziam consigo esse desejo, além dos brasileiros que lá residiam. Se, no início do percurso religioso, elas são arrebatadas por uma sensação de estranhamento ao receberem ainformação de que possuíam uma missão sacerdotal, com o passar do tempo e à medida que foram vivenciando suas práticas, aceitaram a missão que lhes foi confiada pelos orixás e seguiram sua jornada, cuidando de pessoas e caminhos. A aceitação da missão sacerdotal, embora aparentemente se assemelhe a um processo mais passivo, de resignação, simboliza, no percurso dessas mulheres, uma tomada de poder. Esse mesmo orixá que lhes atribuiu tal poder é, desde o início do processo de iniciação até o momento em que são "entronadas" como sacerdotisas, gradativamente introjetado, a tal ponto em que elas se "tornam" o próprio Orixá, em suas características de personalidade e potencialidades.

De acordo com a pesquisadora Marlise Silva (2010), há uma identificação das mulheres no Candomblé, sobretudo as sacerdotisas, com aspectos do feminino que rompem com o ideal da feminilidade ocidental, especialmente atrelado a elementos como passividade, domesticidade e obediência. Assim, essas mulheres se apoiam em arquétipos de deusas guerreiras, mães fortes, mulheres sensuais e temíveis, dotadas de imenso poder, mantenedoras da vida e controladoras da destruição, aspectos esses que podem conviver com alguns mais suaves relacionados à maternagem. Pimpa, Regina e Bárbara entrelaçam as motivações que as levaram a migrar com as epifanias religiosas que explicam o caráter missionário dessa viagem, através do desejo do Orixá de expandir o culto para outras partes do mundo. Nessa viagem a uma terra estrangeira, elas recriaram os conhecimentos que trouxeram consigo, mantendo o possível, recontando histórias, repensando e reinventando suas práticas, ensinando novos adeptos para que possam dar continuidade à religião.

As "Senhoras do Segredo" também são as "Senhoras da Mediação", ou Àwọn İyá İlàjà, porque, de modos diferentes, essas três mulheres reconfiguraram as práticas da religião em Nova Iorque. Elas levaram o culto a uma terra estrangeira e tomaram para si a tarefa de reinventá-lo. Essa necessidade 
de reinvenção é apontada como necessária ao estabelecimento, à difusão e à manutenção do culto. Elas descreveram que, do mesmo modo que os africanos que foram escravizados levaram consigo suas crenças para as Américas, adaptando, escondendo, fundindo, transformando e então dando origem ao Candomblé e a outras religiões de matriz africana, quando ele viaja para outros lugares do Brasil e do mundo, ele também precisa se reinventar. Pimpa se arriscou a dizer que, por tanta reinvenção, as práticas podem sofrer um grau de transformação tal que leve à formação de uma nova religião. Ao mediarem tais reinvenções, elas também acionaram um processo que transpassou o limite das práticas, afetando-as e fazendo com que elas traduzissem a si mesmas. Reinventar o Candomblé pode ser entendido como o processo de "invenção das tradições" proposto por Wagner (1975, p. 240), como um processo dinâmico, criativo e necessário para que um elemento cultural permaneça vivo.

As três mães de santo romperam com o sistema hierárquico vigente no Brasil de relações verticais de poder e estabeleceram conexões com adeptos e clientes de forma mais horizontal. Pimpa e Bárbara relataram um incômodo em relação ao abuso de poder e ao controle da difusão do conhecimento na religião. Regina, não mencionou insatisfação quanto ao sistema hierárquico, possivelmente porque, pelo fato de sua mãe também ter sido iniciada e ter convivido mais tempo em sua vida no Candomblé, numa época anterior às demais, na qual as normas deviam ser mais rígidas e num terreiro mais "tradicional". Pimpa foi iniciada no final dos anos 1970, Bárbara, nos anos 1990 e Regina, no final dos anos 1960. Talvez Regina estivesse mais habituada a esse modelo. Apesar disso, ela apresenta características que destoam de outros sacerdotes: ela tem o hábito de ensinar os consulentes a fazerem suas próprias "magias"; nos encontros durante o campo, ela geralmente teve uma postura bastante humilde e sempre se colocava à disposição para ajudar. No último encontro, ela mencionou que ficava muito feliz em poder ajudar os pesquisadores com as informações e, também, em passar seus ensinamentos, porque, segundo ela, "é uma forma de ajudar a preservar a religião, porque se a pessoa guardar aquele conhecimento para si, leva-o para o caixão". 
Esse estabelecimento de uma relação mais horizontal com a sua clientela, adeptos e filhos de santo pode ser também resultante do modo de interação de um prestador de serviços mágicos numa metrópole como Nova Iorque. É importante levar em consideração que existe uma concorrência nesse tipo de serviço e, ao prestá-lo, existem cuidados que devem ser tomados para evitar denúncias, processos e outros tipos de problemas com a lei. De todo modo, pode-se inferir que o aspecto hierárquico vertical, as cerimônias, as etiquetas cerimoniais não são evidenciados nas práticas rituais realizadas por essas mulheres enquanto sacerdotisas. Entretanto, há uma noção de poder inerente a essas práticas entre elas. Poder esse conferido pelo Orixá. E, no decorrer desse processo, tornam-se conscientes da responsabilidade da função que exercem, desde o processo de saída do país e na coragem de executar as práticas religiosas, mesmo correndo riscos.

As três sacerdotisas comungam aspectos importantes do poder feminino, identificados simbolicamente com as características das deusas no Candomblé: a capacidade de negociação e reinvenções de suas práticas remontam às habilidades das mulheres nos mercados da sociedade iorubá e, ao mesmo tempo, o não excludente exercício da maternagem com clientes e adeptos do culto (SILVA, 2010).

\section{NOTAS FINAIS}

Embora muitas de suas práticas sejam diferentes ou adaptadas, elas não deixam de chamar o que fazem de Candomblé. É uma permissão para reinventar. Essa permissão é dada, de um lado, pelo contexto histórico da viagem do culto aos Orixás no período da escravidão, no qual os africanos trouxeram ao Brasil suas crenças, em parte preservadas, em parte modificadas, adaptadas, em parte suprimidas, perdidas, fusionando pedaços de crenças e diferentes deuses para formar o Candomblé. Por outro lado, são seus Orixás, na consulta ao jogo de búzios, que lhes informam se estão ou não satisfeitos com suas práticas. 
O Candomblé não nasceu no século XIX, ele foi sendo construído desde o início da colonização, para culminar numa forma mais "estável", com a chegada dos iorubás no final do século XVIII e início do XIX. De fato, é uma religião em constante transformação até os dias de hoje. E, embora os praticantes recorram à viagem da África ao Brasil e sua adaptação como forma de sobrevivência, não é o Candomblé que sobreviveu, mas o culto aos Orixás, à custa da formação de uma nova religião (PARÉS, 2006).

As três sacerdotisas evidenciaram uma flexibilização com a estrutura hierárquica vigente nos Candomblés do Brasil. De modos diferentes, considerando suas diferentes histórias de vida, elas trazem em si uma certa "rebeldia", um descontentamento com tais padrões hierárquicos e adotam, em suas práticas, uma postura mais horizontalizada, estabelecendo uma relação de clientela, bem mais condizente com a oferta de "produtos mágicos e religiosos” presente na cidade. Mesmo assim, a noção de responsabilidade, de poder mágico e da missão que acreditam carregar está presente em suas práticas.

Pode-se pensar que, nessa viagem à Nova Iorque, a tradição do Candomblé se reinvente, sendo constantemente traduzido para a língua desse novo local, para poder permanecer, mesmo que modificado. A chegada dessas três mães de santo, bem como de outros sacerdotes, pode ser apenas o início, o momento inicial de instalação da religião, que vai se organizando, estabelecendo-se e, pouco a pouco, replicando modelos de organização e funcionamento parecidos com os Candomblés brasileiros.

\section{REFERÊNCIAS BIBLIOGRÁFICAS}

1. AMARAL, Rita de Cassia de Mello Peixoto. Povo-de-santo, povo de festa: estudo antropológico do estilo de vida dos adeptos do candomblé paulista. 1992. Dissertação (Mestrado em Antropologia Social) - Universidade de São Paulo, São Paulo, 1992.

2. BAHIA, Joana. De Miguel Couto a Berlim: a presença do candomblé brasileiro em terras alemãs. In: PEREIRA, Glória Maria Santiago; PEREIRA, José de Ribalmar 
Sousa (org.). Migração e globalização: um olhar interdisciplinar. Curitiba: CRV, 2012. p. 223-245.

3. CABRERA, Lydia. Iemanjá e Oxum. São Paulo: Edusp, 2004.

4. CAPONE, Stefania. Searching for Africa in Brazil: power and tradition in Candomblé. Durham: Duke University Press, 2010.

5. COMAROFF, John; COMAROFF, Jean. Christianity, colonialism, and consciousness in South Africa. Chicago: University of Chicago Press, 1991. (Of Revelation and Revolution, v. 1).

6. COMAROFF, John; COMAROFF, Jean. The dialetics of modernity on a South African frontier. Chicago: University of Chicago Press, 1997. (Of revelation and revolution, v. 2).

7. COSSARD, Gisele Omindarewa. Awô: o mistério dos Orixás. Rio de Janeiro: Pallas, 2006.

8. COSTA LIMA, Vivaldo da. A família de santo nos candomblés jejês-nagôs da Bahia: um estudo de relações intragrupais. Salvador: Corrupio, 2003.

9. DUMONT, Louis. Homo Hierarchicus: o sistema de castas e suas implicações. São Paulo: EDUSP, 1997.

10. FAVRET-SAADA, Jeanne. Être Affecté. Gradhiva, Paris, v. 8, p. 3-9, 1990.

11. GOLDMAN, Marcio. Histórias, devires e fetiches das religiões afro-brasileiras: ensaio de simetrização antropológica. Análise Social, Lisboa, v. 44, n. 190, p. 105-137, 2009.

12. GOMBERG, Estélio. Hospital de orixás: encontros terapêuticos em um terreiro de candomblé. Salvador: EDUFBA, 2001.

13. IRIART, José Alberto Bernstein. Les femmes dans le candomblé: expérience religieuse et idiome de la possession dans la vie des femmes de Cachoeira, Brésil. 1998. Tese (Doutorado em Antropologia) - Université de Montréal, Montréal, 1998. Disponível em: http://bit.ly/2wYsjcg. Acesso em: $1^{\circ}$ jul. 2017.

14. LIMA, Fábio. As quartas-feiras de xangô: ritual e cotidiano. João Pessoa: Grafset, 2010.

15. MARGOLIS, Maxine. Little Brazil: an ethnography of brazilian immigrants in New York city. Princeton University Press, Princeton, 1994.

16. ORO, Ari Pedro. As religiões afro-brasileiras: religiões de exportação. In: ORO, Ari Pedro (org.). As religiões afro-brasileiras no Cone Sul. UFRGS: Porto Alegre, 1993. p. 39-68. (Cadernos de Antropologia, n. 10).

17. PARÉS, Luis Nicolau. A formação do candomblé: história e ritual da nação jeje na Bahia. Campinas: Ed. Unicamp, 2006. 
18. PORDEUS JR., Ismael. Uma casa luso afro-portuguesa com certeza: emigrações e metamorfoses da umbanda em Portugal. São Paulo: Terceira Margem, 2000.

19. PRANDI, Reginaldo. As religiões negras no Brasil: para uma sociologia dos cultos afro-brasileiros. Revista USP, São Paulo, v. 28, p. 64-83, 1996.

20. PRANDI, Reginaldo. Segredos guardados: orixás na alma brasileira. São Paulo: Companhia das Letras, 2005.

21. SANTOS, Edmar Ferreira. O poder dos candomblés: perseguição e resistência no recôncavo da Bahia. EDUFBA: Salvador, 2009.

22. SCOTT, James. Domination and the arts of resistance: hidden transcripts. New Haven: Yale University Press, 1990.

23. SEGATO, Rita Laura. Santos e daimones: o politeísmo afro-brasileiro e a tradição arquetipal. Brasília: Ed. UnB, 2005.

24. SILVA, Marlise Vinagre. Gênero e religião: o exercício do poder feminino na tradição étnico-religiosa iorubá no Brasil. Revista de Psicologia, Franca, v. 9, n. 2, p. 128-137, 2010.

25. SILVA, Vagner Gonçalves. Candomblé e umbanda: caminhos da devoção brasileira. São Paulo: Ática, 1994.

26. SILVA, Vagner Gonçalves. O antropólogo e sua magia. São Paulo: Edusp, 2000.

27. SODRÉ, Muniz. O terreiro e a cidade. Petrópolis: Vozes, 1988.

28. VERGER, Pierre. Notas sobre o culto aos orixás e voduns. São Paulo: Edusp, 2000.

29. WAGNER, Roy. The invention of culture. Chicago: University of Chicago Press, 1975.

30. ZIEGLER, Jean. Os vivos e a morte. Rio de Janeiro: Zahar, 1977. 